\title{
Primary production in a tropical large lake: The role of phytoplankton composition
}

\author{
F. Darchambeau ${ }^{\text {a }}$, H. Sarmento ${ }^{\text {b }}$, J.-P. Descy ${ }^{\text {c,* }}$ \\ a Chemical Oceanography Unit, University of Liège, Liège, Belgium \\ b Department of Hydrobiology, Federal University of São Carlos, 13565-905 São Carlos, São Paulo, Brazil \\ ${ }^{\text {c }}$ Research Unit in Environmental and Evolutionary Biology, University of Namur, Namur, Belgium
}

\section{H I G H L I G H T S}

- We provide a 7-year dataset of primary production in a tropical great lake.

- Specific photosynthetic rate was determined by community composition.

- Annual primary production varied between 143 and $278 \mathrm{mg} \mathrm{C} \mathrm{m}^{-2} \mathrm{y}^{-1}$.

- Pelagic production was highly sensitive to climate variability.

\section{A R T I C L E I N F O}

\section{Article history:}

Received 17 July 2013

Received in revised form 9 December 2013

Accepted 9 December 2013

Available online 24 December 2013

\section{Keywords:}

Phytoplankton

Photosynthetic parameters

Diatoms

Cyanobacteria

Tropical limnology

Predictive model

\begin{abstract}
A B S T R A C T
Phytoplankton biomass and primary production in tropical large lakes vary at different time scales, from seasons to centuries. We provide a dataset made of 7 consecutive years of phytoplankton biomass and production in Lake Kivu (Eastern Africa). From 2002 to 2008, bi-weekly samplings were performed in a pelagic site in order to quantify phytoplankton composition and biomass, using marker pigments determined by HPLC. Primary production rates were estimated by 96 in situ ${ }^{14} \mathrm{C}$ incubations. A principal component analysis showed that the main environmental gradient was linked to a seasonal variation of the phytoplankton assemblage, with a clear separation between diatoms during the dry season and cyanobacteria during the rainy season. A rather wide range of the maximum specific photosynthetic rate $\left(P_{B m}\right)$ was found, ranging between 1.15 and $7.21 \mathrm{~g}$ carbon $\mathrm{g}^{-1}$ chlorophyll $a \mathrm{~h}^{-1}$, and was best predicted by a regression model using phytoplankton composition as an explanatory variable. The irradiance at the onset of light saturation $\left(I_{k}\right)$ ranged between 91 and $752 \mu \mathrm{E} \mathrm{m}^{-2} \mathrm{~s}^{-1}$ and was linearly correlated with the mean irradiance in the mixed layer. The inter-annual variability of phytoplankton biomass and production was high, ranging from 53 to $100 \mathrm{mg}$ chlorophyll $a \mathrm{~m}^{-2}$ (annual mean) and from 143 to $278 \mathrm{~g}$ carbon $\mathrm{m}^{-2} \mathrm{y}^{-1}$, respectively. The degree of seasonal mixing determined annual production, demonstrating the sensitivity of tropical lakes to climate variability. A review of primary production of other African great lakes allows situating Lake Kivu productivity in the same range as that of lakes Tanganyika and Malawi, even if mean phytoplankton biomass was higher in Lake Kivu.
\end{abstract}

(C) 2013 Elsevier B.V. All rights reserved.

\section{Introduction}

Contrary to common assumptions on the constancy of ecological conditions in tropical lakes, pelagic primary production may vary considerably in African great lakes, at different time scales, from seasons to centuries (Melack, 1979; Cohen et al., 2006). At long time scales, Indian Ocean surface temperatures, determining rainfall, are the primary influence on East African climate (Tierney et al., 2013), which largely determines water column processes in the great Rift lakes (e.g. Johnson

\footnotetext{
* Corresponding author. Tel.: + 3281724405 .

E-mail addresses: francois.darchambeau@ulg.ac.be (F. Darchambeau), hugo.sarmento@gmail.com (H. Sarmento), jean-pierre.descy@unamur.be (J.-P. Descy).
}

and Odada, 1996; Plisnier, 2000; MacIntyre, 2012). At a seasonal scale, the main driver of pelagic primary production is the alternation of wet and dry seasons, with changes in relative humidity and wind velocities: typical wet season conditions induce thermal stratification of the water column, which reduces nutrient supply in the euphotic zone. Dry season conditions tend to reduce the temperature-density gradient and higher wind velocities result in deep vertical mixing of the water column, increasing nutrient supply in the euphotic zone, inducing a dry season phytoplankton peak (Hecky and Kling, 1987; Spigel and Coulter, 1996).

Phytoplankton composition also depends on the alternation of stratified conditions in the rainy season with the deep mixing that occurs in the dry season: the seasonal mixing event not only increases the supply of dissolved nutrients in the euphotic zone, but also results in a rise of the ratio between mixed layer depth $(\mathrm{Zm})$ to the euphotic layer depth 
(Zeu) (Sarmento et al., 2006). In these conditions, phytoplankton is subjected to potential light limitation, leading to diatom dominance (Reynolds, 2006a). By contrast, in the shallow mixed layer of the rainy season, the lower Zm:Zeu ratio selects for high-light adapted phytoplankton such as green algae and cyanobacteria. The trade-off between high light and nutrient limitation in the rainy season and low light and high nutrients during the dry season has been documented in classic studies in African lakes (e.g. Hecky and Kling, 1987; Kilham et al., 1986) and is a key to understanding shifts in phytoplankton composition in these lakes.

Estimates of annual primary productivity in tropical lakes have been usually based on measurements of phytoplankton photosynthesis carried out over sufficiently long periods to capture the seasonal variations of incident light, water transparency, temperature, nutrients and phytoplankton biomass. Examples of this approach can be found in Lewis (1974) in Lake Lanao (Philippines), in Talling (1965) for several East African lakes, in Hecky and Fee (1981), Sarvala et al. (1999) and Stenuite et al. (2007) for Lake Tanganyika, in Guildford et al. (2007) for Lake Malawi and in Silsbe et al. (2006) for Lake Victoria. Such studies derived photosynthetic parameters $\left(P_{B m}\right.$, the maximum specific photosynthetic rate, and $I k$ or $\alpha$, a measure of the photosynthetic efficiency) from in situ incubations. If the irradiance at the onset of light saturation (Ik) describes the regulatory response of the phytoplankton photosynthesis to the light climate, $P_{B m}$ relates to the efficiency of the light harvesting system. Main environmental factors influencing $P_{B m}$ in cultures are temperature and nutrient availability (Geider and MacIntyre, 2002). A reduction of $P_{B m}$ is observed in nutrient-limited algae (Geider et al., 1998; Greene et al., 1991). At the community level, it has occasionally been demonstrated that larger cells sustain higher $P_{B m}$ than smaller cells (Cermeño et al., 2005; Peltomaa and Ojala, 2010), but field studies attempting to relate the compound photosynthetic response on the taxonomic composition of the phytoplankton assemblage are rare (Segura et al., 2013). However, phytoplankton composition matters, as shown by experimental studies on pure cultures, which have provided evidence of significant variation of photosynthetic parameters among taxonomic groups (Falkowski and Raven, 2007; Kirk, 1994; Reynolds, 2006a).

Pigment-based analysis of phytoplankton composition may provide an adequate framework to relate community composition to photosynthesis parameters. Phytoplankton pigments, determined by high performance liquid chromatography (HPLC) analysis, have been used widely for assessing biomass at the class level, with many applications in marine, estuarine, and freshwater environments (e.g., review in Sarmento and Descy, 2008). The assessment of algal abundance from pigment concentrations uses different techniques, involving ratios of marker pigments to chlorophyll $a$ (Chla) (Mackey et al., 1996). As it is based on a fast, automatic and reliable analytical technique, the pigment approach has been largely used in oceanographic studies and monitoring programs (Jeffrey et al., 1997), as well as in large lake studies (Descy et al., 2005; Fietz and Nicklish, 2004; Fietz et al., 2005; Sarmento et al., 2006).

We applied a pigment approach in Lake Kivu, a great and deep ( $\max -$ imum depth of $489 \mathrm{~m}$ ) meromictic lake of the East African Rift (Fig. 1). Lake Kivu is located north of Lake Tanganyika, at $1463 \mathrm{~m}$ above sea level. The mixolimnion (i.e. the upper layer of a meromictic lake) alternates between periods of complete mixing down to maximum $65 \mathrm{~m}$ and periods of stratification during which nutrients become depleted in the euphotic zone (Sarmento et al., 2006; Schmid and Wüest, 2012). Whereas moderate to severe P-limitation of phytoplankton prevails during most of the year (Sarmento et al., 2009, 2012), N-limitation may occur in the stratified rainy season, as denitrification takes place within the oxic-anoxic transition zone (Llirós et al., 2012). By contrast, the monimolimnion, i.e. the lower layer that never mixes with surface waters, is rich in nutrients and dissolved gases (Degens et al., 1973; Schmid et al., 2005). Pelagic primary production in Lake Kivu exhibits substantial variation at the seasonal scale, but also between years

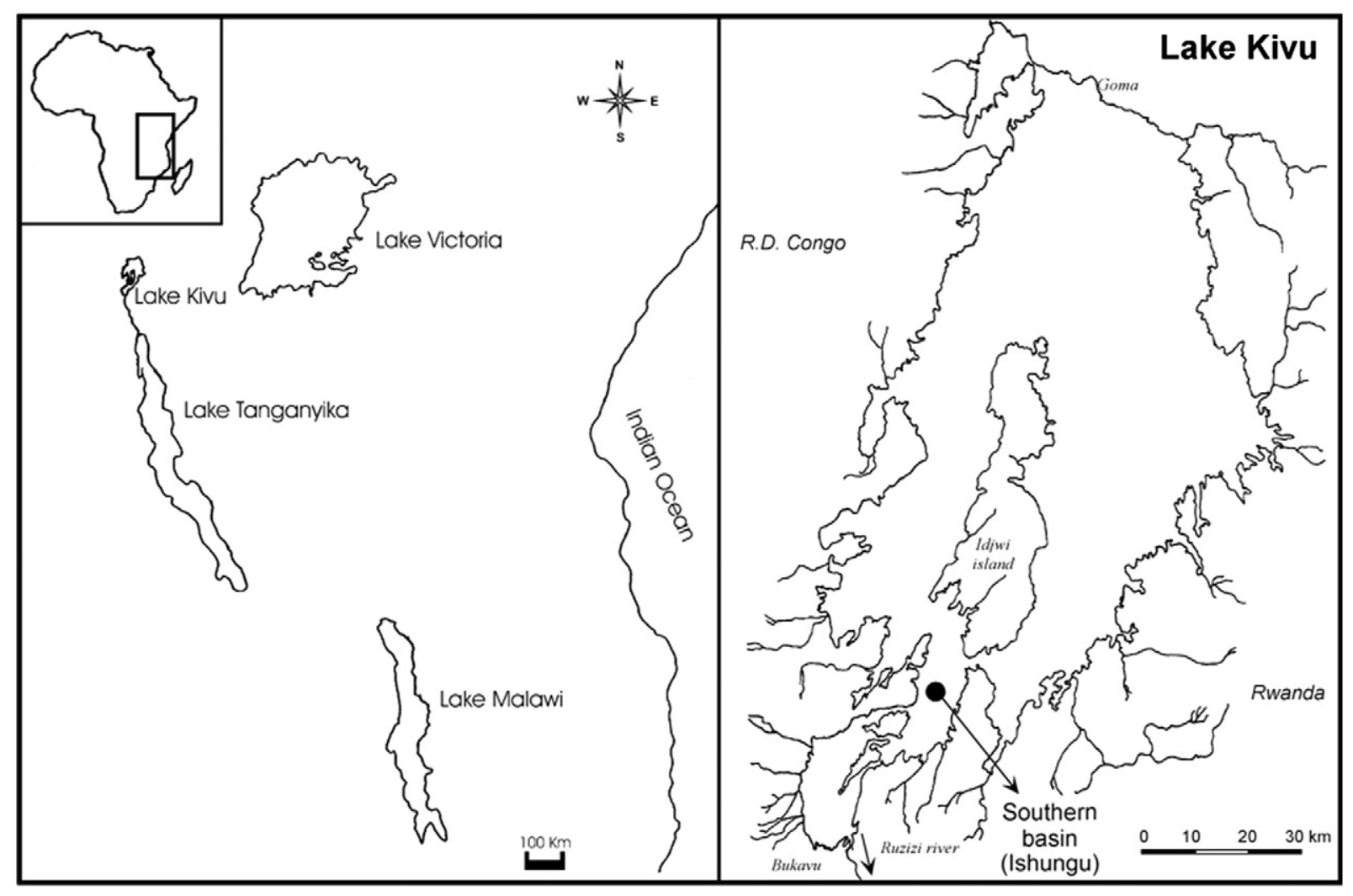

Fig. 1. Location of Lake Kivu in East Africa (left panel) and the sampling site (Ishungu, southern basin). 
(Sarmento et al., 2012), as shown by the variable height of the dry season Chla peak. Phytoplankton composition also varies seasonally in a typical way, with diatoms and cryptophytes being more abundant in the dry season, and cyanobacteria better developed in the rainy season (Sarmento et al., 2006, 2007).

Our working hypothesis was that in this tropical great lake, phytoplankton composition, along with water transparency and depth of the mixed layer, is a key factor determining pelagic photosynthesis. We used a long-term database of in situ photosynthesis measurements and phytoplankton composition, determined by HPLC analysis of marker pigments, to demonstrate that the photosynthetic parameters, $P_{B m}$ and $I k$, can be derived from quantitative composition of the phytoplankton assemblage, allowing accurate prediction of daily and annual primary production.

\section{Material and methods}

\subsection{Sampling}

The study site was located in the southern basin (Ishungu) of Lake Kivu $\left(2.34^{\circ} \mathrm{S}, 28.98^{\circ} \mathrm{E}\right)$ (Fig. 1). General physico-chemical characteristics of the lake's water are described elsewhere (e.g. Borges et al., 2011; Descy et al., 2012; Sarmento et al., 2006; Schmid et al., 2005). Limnological observations were made twice a month from March 2002 to November 2009. First, vertical profiles of temperature were obtained with a Hydrolab DS4a probe or a Yellow Springs Instrument 6600 V2 probe. The mixed layer depth, $Z m$, was determined at each occasion as the depth with the maximum downward temperature change per meter, based on the fact that salinity has a marginal effect on density gradient in the top $65 \mathrm{~m}$ (Schmid and Wüest, 2012). Water samples were collected at discrete depth intervals $(0,5,10,15,20,25,30,40$, 50 and $60 \mathrm{~m}$ depth) using a $6 \mathrm{~L}$ Van Dorn bottle. For each sampling depth, at least $3 \mathrm{~L}$ of water were filtered on Macherey-Nägel (Düren, Germany) GF5 filters (average retention capacity of $0.4 \mu \mathrm{m}$ ) which were immediately frozen at $-20{ }^{\circ} \mathrm{C}$ for pigment analysis. For the primary production incubation (see below), a pooled sample was constituted on each sampling occasion from discrete samples (2 L) spaced every $5 \mathrm{~m}$ in the mixed layer. In addition, at least $3 \mathrm{~L}$ of water was filtered from the pooled mixed layer sample for pigment analysis and $2 \mathrm{~L}$ was filtered on a pre-combusted GF5 filter for particulate carbon $(\mathrm{C})$, nitrogen $(\mathrm{N})$ and phosphorus $(\mathrm{P})$ analyses. Filters were kept frozen until analysis.

\subsection{Phytoplankton biomass}

Chla was used as an index of phytoplankton biomass (Reynolds, 2006a). Total phytoplankton biomass and the contribution of the different algal groups were achieved by HPLC analysis of marker pigments. It was demonstrated that the accuracy of Chla and chemotaxonomic carotenoid quantification by HPLC is less than 10 and $25 \%$, respectively (Claustre et al., 2004). Data were subsequently processed with CHEMTAX (for CHEmical TAXonomy) (Mackey et al., 1996), as described in Descy et al. (2005) and Sarmento et al. (2006). CHEMTAX is a computer program that allows allocating Chla among different algal groups defined by a suite of markers. From an initial ratio matrix (or input matrix) usually derived from pure cultures of phytoplankton, the program uses an iterative process to find the optimal pigment:Chla ratios and generates the fraction of the total Chla pool belonging to each pigment-determined group (Mackey et al., 1996). A supplementary $50 \mathrm{~mL}$ sample was preserved immediately after collection with Lugol's solution and neutral formaldehyde (2-4\% final concentration) for microscopic identification of main taxa, according to Sarmento et al. (2007). Phytoplankton biomass was expressed either as $\mathrm{mg}$ Chla $\mathrm{m}^{-3}$

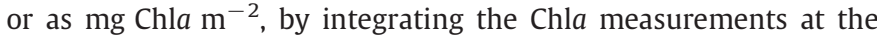
different sampled depths over the whole mixolimnion (0-65 m).

\subsection{Primary production}

The primary production rate was determined in 96 field photosynthesis-irradiance incubations. Eighteen 120-mL (from 2003 to 2005) or $20180-\mathrm{mL}$ (from 2006 to 2008) glass flasks were filled with water from the pooled mixed layer sample and $50 \mu \mathrm{Ci}$ of $\mathrm{NaH}^{14} \mathrm{CO}_{3}$ was added into each flask. Duplicate sets of bottles were placed into a ten-case floating incubator providing a range from 0 to $90 \%$ of natural light energy and incubated in situ at mid-day for $\sim 2 \mathrm{~h}$ just below the surface. Incident light was monitored by a Li-Cor (Lincoln, Nebraska, USA) quantum sensor throughout the incubations.

The incubation was stopped by adding neutral formaldehyde and the phytoplankton was collected on Macherey-Nägel GF5 filters. Filters were rinsed with $\mathrm{HCl} 0.1 \mathrm{~N}$ and the radioactivity of the filters was measured using a Beckman scintillation counter (LS 6000 SC) with Filter-Count (Packard) as scintillation cocktail and the external standard method for quench correction. The specific photosynthetic rate of individual bottle $i, P_{i}$ (in $\mathrm{mg} \mathrm{C} \mathrm{mg}^{-1} \mathrm{Chla} \mathrm{h}^{-1}$ ), was calculated following Steeman-Nielsen (1952). Dissolved inorganic carbon (DIC, in

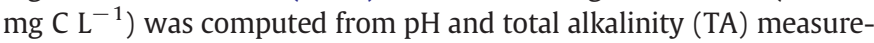
ments using the carbonic acid dissociation constants of Millero et al. (2006). Measurements of TA were carried out by open-cell titration with $\mathrm{HCl} 0.1 \mathrm{M}$ according to Gran (1952) on $50 \mathrm{~mL}$ water samples.

For each experiment, the maximum specific photosynthetic rate $P_{B m}$ (in $\mathrm{mg} \mathrm{C} \mathrm{mg}^{-1} \mathrm{Chla} \mathrm{h}^{-1}$ ) and the irradiance at the onset of light saturation $I_{k}\left(\mu \mathrm{E} \mathrm{m}^{-2} \mathrm{~s}^{-1}\right)$ were determined by fitting $P_{i}$ to the irradiance gradient provided by the incubator $I_{i}\left(\mu \mathrm{E} \mathrm{m} \mathrm{m}^{-2} \mathrm{~s}^{-1}\right)$, using the Vollenweider's (1965) equation, with the photo inhibition parameters set to 1 :

$P_{i}=2 P_{B m} \frac{\frac{I_{i}}{2 I_{k}}}{1+\left(\frac{I_{i}}{2 I_{k}}\right)^{2}}$.

Fitting was performed using the Gauss-Newton algorithm for nonlinear least squares regression with the help of the STATISTICA $10^{\circ}$ software (StatSoft France). The vertical light attenuation coefficient (Kirk, 1994), $K_{e}\left(\mathrm{~m}^{-1}\right)$, was calculated from simultaneous measurements of surface irradiance with a Li-Cor LI-190 Quantum Sensor and underwater PAR measurements with a submersible Li-Cor LI-193SA Spherical Quantum Sensor. $K_{e}$ was derived from the slope of the semi-logarithmic regression between relative quantum irradiance and depth (from 0 to $20 \mathrm{~m}$ ). From 2003 to 2006, $K_{e}$ was derived from Secchi depth, $S D(\mathrm{~m})$, using a conversion factor $K_{e}=-\ln (0.25) / S D$ obtained by calibration with PAR downward attenuation $(n=16$, Pearson $r=0.81$, $p<0.001$ ). The euphotic depth, $Z_{e u}$, was defined as the depth at which light is $1 \%$ of subsurface light. The average light in the mixed layer, $I_{Z m}$ (in $\mu \mathrm{E} \mathrm{m}^{-2} \mathrm{~s}^{-1}$ ), was calculated according to Riley (1957):

$I_{Z_{m}}=\frac{I s\left(1-e^{-Z_{m} \cdot K_{e}}\right)}{Z_{m} \cdot K_{e}}$

where $I_{S}$ is the mean solar flux at the surface of the lake (24 h average) and $Z_{m}$ is the depth of the mixed layer. $I_{S}$ was calculated for a theoretical cloudless atmosphere for the appropriate latitude (Fee, 1990).

Daily depth-integrated primary production (DPP, in $\mathrm{g} \mathrm{C} \mathrm{m}^{-2} \mathrm{~d}^{-1}$ ) was determined using photosynthetic parameters $P_{B m}$ and $I_{k}$, Chla biomass vertical profile, vertical light attenuation coefficient $K_{e}$ and continuous surface irradiance data (Kirk, 1994), calculated for a theoretical cloudless atmosphere for the appropriate latitude (Fee, 1990):

$\mathrm{DPP}=\int_{0}^{24 h} \int_{0}^{z_{m}} 2 P_{\mathrm{Bm}} B_{z} \frac{\frac{I_{z, t}}{2 I_{k}}}{1+\left(\frac{I_{z, t}}{2 I_{k}}\right)^{2}} \mathrm{~d} z \mathrm{~d} t$ 
Table 1

Description of the variables used for modeling primary production.

\begin{tabular}{|c|c|c|c|}
\hline Symbol & Description & Unit & Data source \\
\hline $\mathrm{B}_{\mathrm{z}}$ & Chlorophyll $a$ biomass at depth $z$ & $\mathrm{mg}$ Chla $\mathrm{m}^{-3}$ & Field observations \\
\hline DPP & Daily depth-integrated primary production & $\mathrm{g} \mathrm{C} \mathrm{m}^{-2} \mathrm{~d}^{-1}$ & Eq. (3) \\
\hline$I_{0, t}$ & Surface irradiance at time $t$ & $\mu \mathrm{E} \mathrm{m}^{-2} \mathrm{~s}^{-1}$ & Solar modeling (Fee, 1990) \\
\hline$I_{k}$ & Irradiance at the onset of light saturation & $\mu \mathrm{E} \mathrm{m}^{-2} \mathrm{~s}^{-1}$ & Field experiment or Eq. (5) \\
\hline$I_{S}$ & Mean solar flux at the surface of the lake during the day ( $24 \mathrm{~h}$ average) & $\mu \mathrm{E} \mathrm{m}^{-2} \mathrm{~s}^{-1}$ & Solar modeling (Fee, 1990) \\
\hline$I_{Z m}$ & Average light in the mixed layer & $\mu \mathrm{E} \mathrm{m}^{-2} \mathrm{~s}^{-1}$ & Eq. (2) \\
\hline$I_{z, t}$ & Irradiance at depth $z$ and time $t$ & $\mu \mathrm{E} \mathrm{m}^{-2} \mathrm{~s}^{-1}$ & Eq. (4) \\
\hline$K_{e}$ & Vertical light attenuation coefficient & $\mathrm{m}^{-1}$ & Field observations \\
\hline$P_{B m}$ & Maximum specific photosynthetic rate & $\mathrm{mg} \mathrm{C} \mathrm{mg}^{-1} \mathrm{Chla} \mathrm{h}^{-1}$ & Field experiment or Eq. (6) \\
\hline PCAaxis1 & Score of pigment-based phytoplankton composition on the 1st axis of the PCA & No unit & HPLC analyses of field samples \\
\hline PCAaxis2 & Score of pigment-based phytoplankton composition on the 2nd axis of the PCA & No unit & HPLC analyses of field samples \\
\hline$z_{m}$ & Mixed layer depth & $\mathrm{m}$ & Field observations \\
\hline
\end{tabular}

with:

$$
I_{z, t}=0.95 I_{o, t} e^{-K_{e} z}
$$

All symbols and units are described in Table 1.

\subsection{Particulate CNP}

Particulate C and N were analyzed using a Carlo-Erba NA1500 elemental analyzer. Particulate P was analyzed by spectrophotometric determination of phosphate after digestion with potassium persulfate and boric acid (Valderrama, 1981). The elemental ratios were expressed as the mean ratio in molar units of the different sampling dates.

\subsection{Statistical analysis}

A principal component analysis (PCA) was performed on the relative contribution of the different phytoplankton groups to Chla resulting from the CHEMTAX processing. In total, 1387 individual HPLC samples from Lake Kivu were used. The PCA was carried out with the help of the CANOCO software (ter Braak and Šmilauer, 2002) after centering and standardization of the relative contributions to total Chla biomass. Results of the PCA ordination, i.e. sample scores along the first factorial axis, were used as independent variables to explain the maximum specific photosynthetic rate, $P_{B m}$, of the different photosynthesis experiments. The reason for using the PCA axes instead of phytoplankton relative class abundances was to avoid autocorrelation between independent variables (Legendre and Legendre, 1998). The effects of the season along PCA axes were tested using Student's t statistical tests. Simple and multiple linear regressions were performed to explain variations of photosynthetic parameters, $I_{k}$ and $P_{B m}$, with, respectively, light conditions in the water column and phytoplankton community composition and CNP ratios. Multiple linear regressions were achieved using a forward stepwise selection of explanatory variables. Statistical tests, i.e. simple and multiple linear regressions and Student's t-test, were carried out with the help of the STATISTICA $10^{\odot}$ software (StatSoft France). Daily primary production was calculated using Eq. (4) with observed or statistically-derived photosynthetic parameters. A sensitivity analysis of the primary production model was performed by replacing each variable by its mean in turn, while holding all other variables at their original values. The mean absolute relative error of daily primary production was then computed for each variable.

\section{Results}

Phytoplankton composition and biomass are presented in Fig. 2 . The community was dominated by cyanobacteria, diatoms and cryptophytes. A seasonal peak higher than $100 \mathrm{mg}$ Chla $\mathrm{m}^{-2}$ was observed at the end of the dry season (July-August) in 2003, 2004 and more spectacularly in 2008. A lower dry season peak was observed in
2006 and 2007. These peaks were mainly constituted of diatoms (essentially Nitzschia bacata Hust. and Fragilaria danica Lange Bert.). By contrast, cyanobacteria developed best during the rainy season, from October to May. The most common cyanobacteria taxa present in Lake Kivu were Planktolyngbya limnetica Lemm., Synechococcus spp. and various Microcystis species. The cryptophyte Rhodomonas was present throughout the year.

The inter-annual variability of phytoplankton biomass was relatively high, with the lowest mean annual biomass observed in 2005 with $53 \mathrm{mg} \mathrm{Chla} \mathrm{m} \mathrm{m}^{-2}$ and the highest in 2008 with $100 \mathrm{mg} \mathrm{Chla} \mathrm{m} \mathrm{m}^{-2}$. The inter-annual coefficient of variation (CV) from 2002 to 2008 was $21 \%$.

The seasonal variation of the mixed layer depth is presented in Fig. 2C. The dry season (from June to August) was characterized by a deeper mixed layer, although this pattern was not consistent over the years.

The PCA carried out on the relative contribution of each phytoplankton group to the total Chla biomass confirmed that the first component was linked to the seasonal variations (Fig. 3). The first axis, which represents $30.5 \%$ of the total variance, separates diatoms and chlorophytes from cyanobacteria. This axis clearly separates rainy season samples, with generally negative values (mean value, -0.19 ), from dry season samples, with positive values (mean value, +0.31 ) (Student's t-test, $p<0.001$ ). The second axis collects $22.0 \%$ of the total variance and dissociates cryptophytes from the other groups. This axis is independent on the seasonal succession (Student's t-test, $p=0.112$ ).

The depth of the euphotic zone, $Z_{\text {eu }}$, ranged between 8.3 and $28.5 \mathrm{~m}$ (median, $17.6 \mathrm{~m}$ ) (Fig. 2D). The highest transparencies were observed at the end of the rainy season, in June, and sometimes in July and August, depending on the year. As expected, phytoplankton biomass directly influenced water transparency (Fig. 4).

Mean ( \pm standard deviation) seston $\mathrm{C}, \mathrm{N}$ and $\mathrm{P}$ concentrations were $458( \pm 113) \mu \mathrm{g} \mathrm{C} \mathrm{L}{ }^{-1}, 56( \pm 12) \mu \mathrm{g} \mathrm{N} \mathrm{L}^{-1}$ and $5.2( \pm 1.8) \mu \mathrm{P} \mathrm{L} \mathrm{L}^{-1}$. Seasonal variations of the seston C:N:P molar ratios are presented in Fig. 5. The C:N ratio (mean 10.1, min-max 6.3-14.4) was largely influenced by season, with lower values at the end of dry season (July-August) than in the rest of year $(p<0.005)$. Nevertheless, dry season values (June-August) were the most variable, depending on the year. The C:P ratio (mean 263, min-max 130-447) was also largely influenced by season, with decreasing values from December to June and increasing values from July to November. The seasonal pattern was consistent over the years.

The photosynthetic parameters were estimated at 96 occasions from 2002 to 2008. An example of the photosynthesis vs irradiance curve we usually obtained is illustrated in Fig. 6. The fitting to the Vollenweider's model (Eq. (1)) was usually good, with a $R^{2}>0.95$. The irradiance at the onset of light saturation, $I_{k}$, ranged between 91 and $752 \mu \mathrm{E} \mathrm{m}^{-2} \mathrm{~s}^{-1}$ (mean $318 \mu \mathrm{E} \mathrm{m}^{-2} \mathrm{~s}^{-1}$ ). It was linearly correlated to the mean irradiance in the mixed layer, $I_{Z m}$ (Fig. 7).

The maximum specific photosynthetic rate, $P_{B m}$, ranged between 1.15 and $7.21 \mathrm{~g} \mathrm{C} \mathrm{g}^{-1} \mathrm{Chla} \mathrm{h}^{-1}$ (mean $3.57 \mathrm{~g} \mathrm{C} \mathrm{g}^{-1} \mathrm{Chla} \mathrm{h}^{-1}$ ). Simple and multiple linear regressions were tested to explain the variability of 

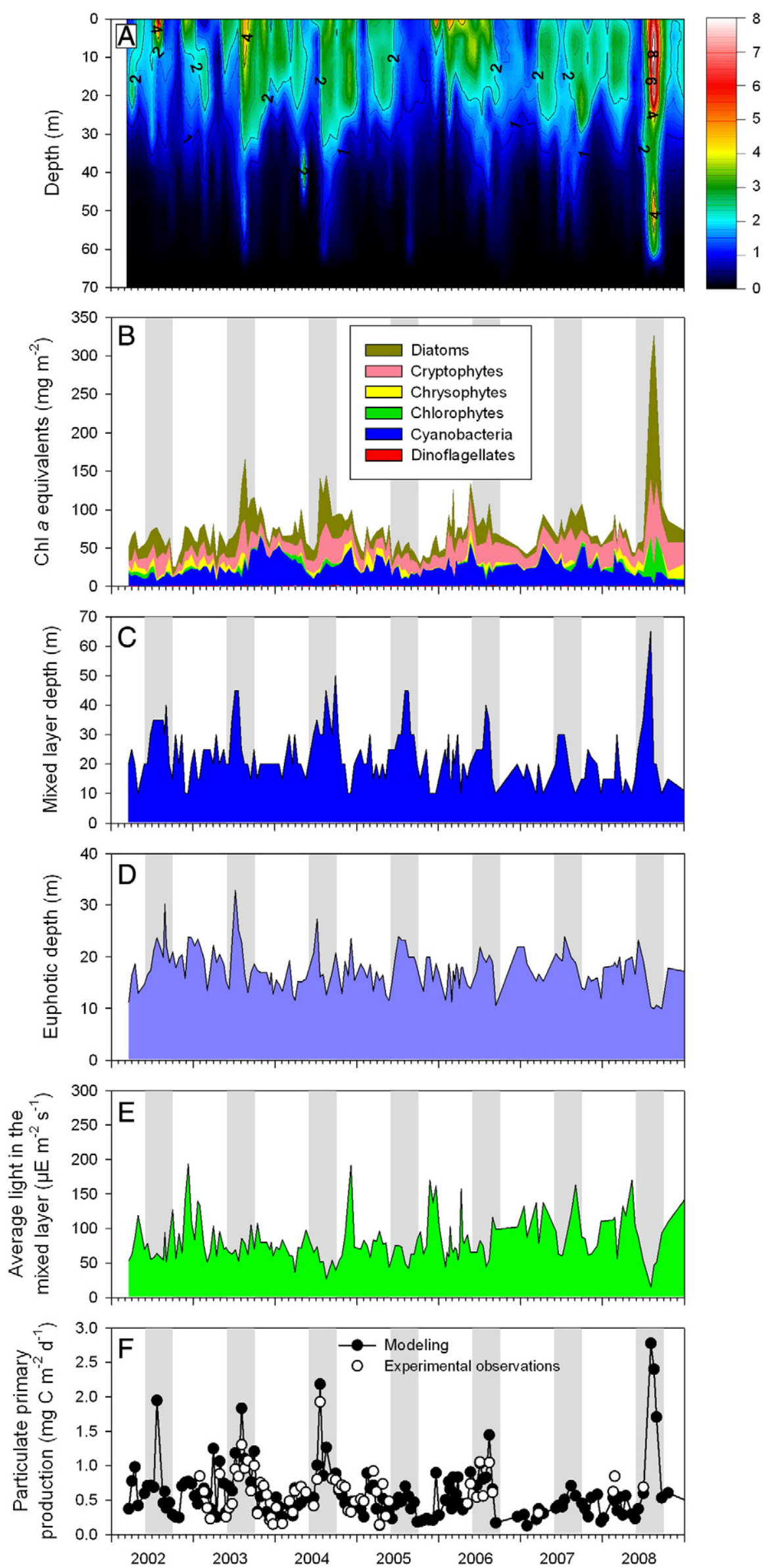

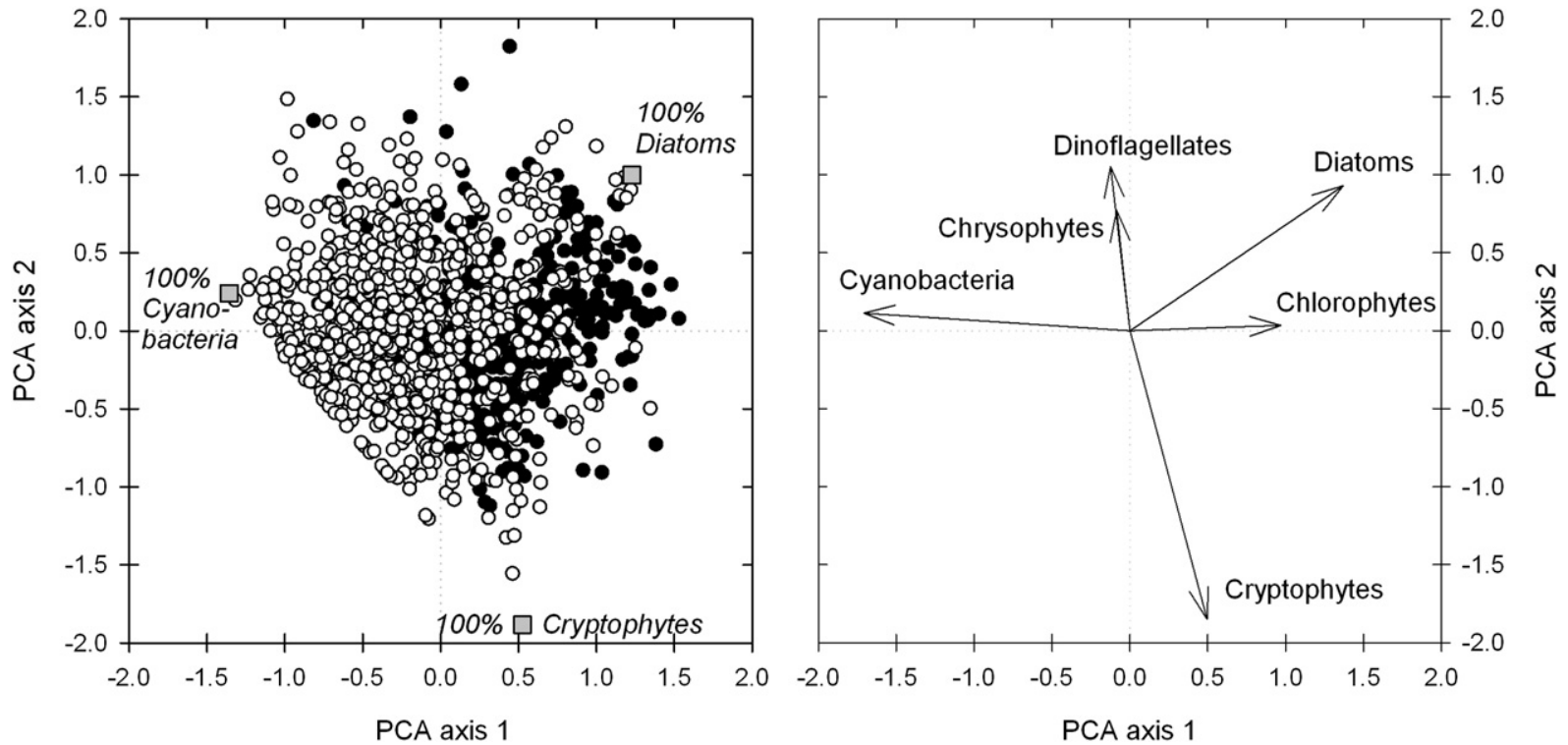

Fig. 3. Principal component analysis (PCA) of the relative contribution of the main phytoplankton groups to chlorophyll $a$ from Lake Kivu, Ishungu station (southern basin); left panel: diagram of the samples on the two first axes of the PCA, showing a clear separation depending on season (open circles: samples from the rainy season; black circles: dry season) and the position of hypothetical "pure" phytoplankton group samples; right panel: diagram of the phytoplankton groups on the two first axes of the PCA.

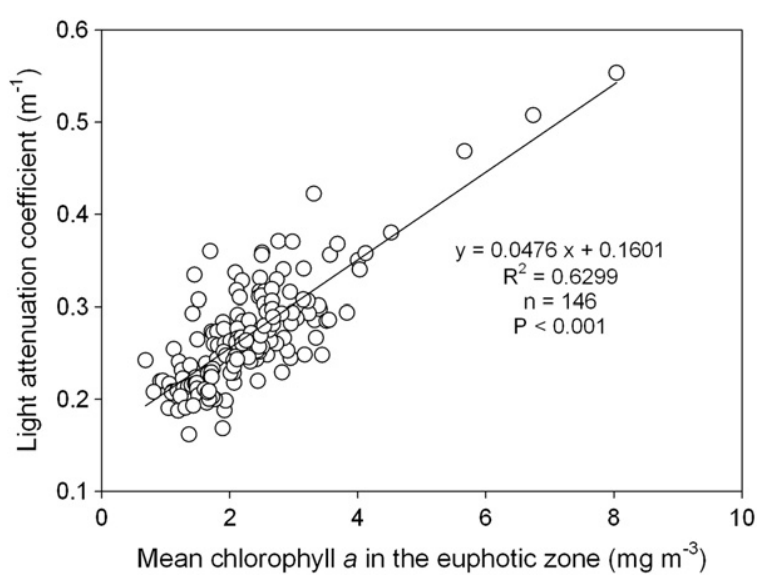

Fig. 4. Linear regression of the vertical attenuation of light against mean chlorophyll a concentration in the euphotic layer in Lake Kivu, Ishungu station (southern basin), 2002-2008.

$P_{B m}$ using phytoplankton composition, represented by the sample position along the first 4 axes of the PCA, and C:N and C:P ratios as explanatory variables. $P_{B m}$ was significantly correlated with axis $1(r=0.779$; $p<0.001)$ and axis $2(r=0.321 ; p=0.001)$ of the PCA. $P_{B m}$ was also negatively correlated with seston C:P ratios $(r=-0.448 ; p<0.001)$. A multiple linear regression was constructed with a forward stepwise selection of significant variables (Table 2). A single model with the first two axes of the PCA, significant at the 0.05 probability level, explained around $66 \%$ of the $P_{B m}$ variance (Table 2 and Fig. 8 ). As the C:P ratios were negatively correlated with the first PCA axis $(r=-0.49$, $p<0.001$ ), both variables explained a common variance of $P_{B m}$. This explains why the $\mathrm{C}: \mathrm{P}$ ratio was not significant to explain $P_{B m}$ when the first PCA axis was already included in the regression model.

$P_{B m}$ was positively correlated with the sample score along the first and the second axes of the PCA: this results from the fact that $P_{B m}$ was higher for a phytoplankton assemblage dominated by diatoms than when phytoplankton was dominated by cyanobacteria and/or cryptophytes. Three fictive HPLC samples with communities composed exclusively of cyanobacteria, diatoms or cryptophytes were added as passive samples in the PCA (see Fig. 3). The position of these communities along the first 2 axes was used within the multiple linear regression model presented in Table 2, to calculate the $P_{B m}$ values for "pure" communities in Lake Kivu. The calculated $P_{B m}$ was $1.13 \mathrm{~g} \mathrm{C} \mathrm{g}^{-1} \mathrm{Chl} \mathrm{h}^{-1}$ for cyanobacteria, $2.36 \mathrm{~g} \mathrm{C} \mathrm{g}^{-1} \mathrm{Chla} \mathrm{h}^{-1}$ for cryptophytes, and $7.21 \mathrm{~g} \mathrm{C} \mathrm{g}^{-1}$ Chla $\mathrm{h}^{-1}$ for diatoms.

The daily primary production was calculated based upon observed and statistically-derived photosynthetic parameters. $I_{k}$ was modeled using the linear regression model including $I_{Z m}$ as single explanatory variable (Fig. 7):

$I_{k}=43.7+3.67 I_{z_{m}}$

and $P_{B m}$ values were obtained from the multiple linear regression model presented in Table 2:

$P_{B m}=3.56+2.001$ PCAaxis $1+1.196$ PCAaxis 2.

Daily primary production results are presented in Fig. 2F. The mean daily primary production based upon observed photosynthetic parameters was $0.620 \mathrm{~g} \mathrm{C} \mathrm{m}^{-2} \mathrm{~d}^{-1}$ (range $0.142-1.924$ ). Daily primary production values calculated from observed or statistically-derived photosynthetic parameters were highly correlated $\left(R^{2}=0.787\right)$ and not statistically different (Student's t-test for paired samples, $n=59$, $P=0.206$ ). Annual primary production was then calculated based on statistically-derived photosynthetic parameters. The mean annual primary production from 2002 to 2008 was $213 \mathrm{~g} \mathrm{C} \mathrm{m}^{-2} \mathrm{y}^{-1}$. The inter-annual variation was important $(\mathrm{CV}=25 \%)$, with a minimum value of $143 \mathrm{~g} \mathrm{C} \mathrm{m}^{-2} \mathrm{y}^{-1}$ in 2007 and a maximum value of $278 \mathrm{~g} \mathrm{C} \mathrm{m}^{-2} \mathrm{y}^{-1}$ in 2008.

Input variables of the primary production model are the phytoplankton biomass (Chla), the photosynthetic parameters $\left(P_{B m}\right.$ and $\left.I_{k}\right)$, the

Fig. 2. (A) Vertical distribution of phytoplankton biomass (Chlorophyll $a, \mathrm{mg} \mathrm{m}^{-3}$ ), (B) areal chlorophyll $a$ concentrations and biomass composition from marker pigment analysis, (C) depth of the mixed layer, (D) depth of the euphotic layer, (E) average light in the mixed layer, (F) daily depth-integrated primary production with photosynthetic parameters estimated from in situ ${ }^{14} \mathrm{C}$ incubations (white circles) or with photosynthetic parameters calculated from Eqs. (5) and (6) (black circles with lines), during the 2002-2008 period in Lake Kivu, Ishungu station (southern basin). The gray boxes identify the main dry season periods. 

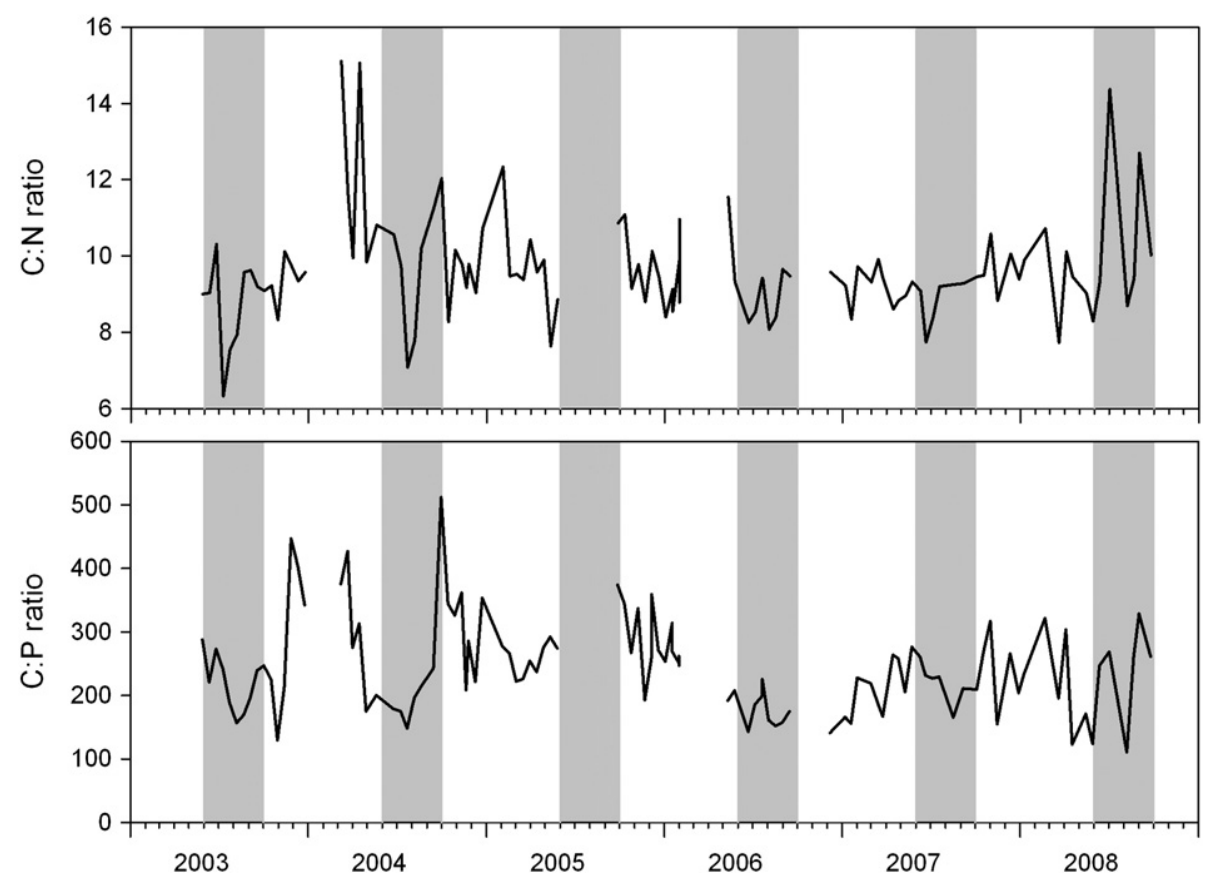

Fig. 5. C:N:P elemental ratios (atomic values) of epilimnetic seston in Ishungu station (southern basin) of Lake Kivu from 2003 to 2008 . The gray boxes identify the main dry season periods.

depth of the mixed layer $\left(Z_{m}\right)$, the vertical light attenuation coefficient $\left(K_{e}\right)$, and indirectly (via its influence on $P_{B m}$ ) the phytoplankton community composition (PCAaxis1). Results of the sensitivity analysis of the primary production model are presented in Table 3. Chla was the most influential variable of the daily primary production, followed by the photosynthetic parameters. The physical variables, such as $Z_{m}$ and $K_{e}$ had only minor influence.

\section{Discussion}

In this study, we present results on phytoplankton assemblage, biomass and production obtained during a 7-year continuous survey in Lake Kivu, a large tropical lake of East Africa. Such a dataset is unique for East African Great lakes and provides evidence for substantial variations of phytoplankton biomass and production between years. From these data, we developed an empirical model of planktonic primary

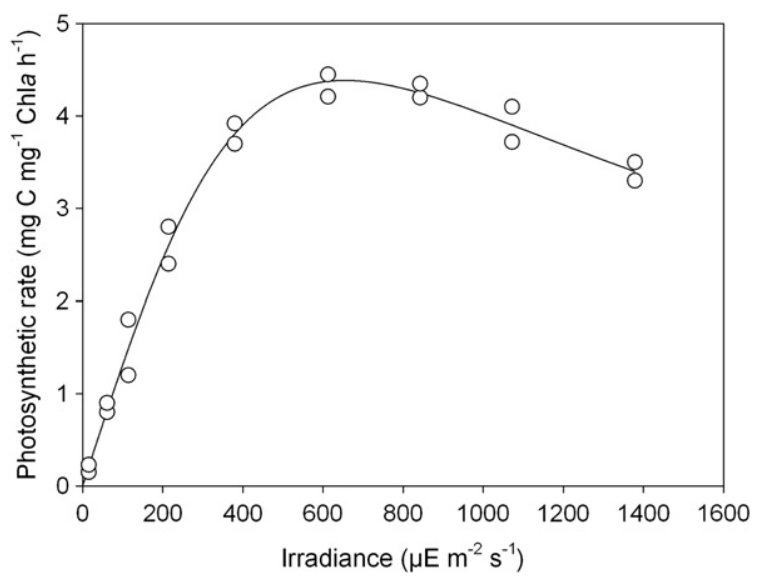

Fig. 6. Example of a photosynthesis-light relationship obtained from an in situ radiocarbon incubation under light saturation in Lake Kivu (July 3rd, 2008). White circles are for the rates estimated from the incubated bottles while the line shows the rates estimated from Vollenweider's equation (Eq. (1)) fitted to the incubation results $\left(R^{2}=0.989\right)$. production which can be used for deriving photosynthetic parameters based upon phytoplankton community composition and light conditions.

In Lake Kivu, phytoplankton generally peaks in the main dry season (June-September) (Fig. 2), when enhanced lake evaporation causes a significant heat loss from the lake surface, allowing a reduction of the thermal gradient in the mixolimnion (Sarmento et al., 2006). Surface waters are then mixed with deeper waters enriched in nutrients, allowing adequate conditions for phytoplankton development. Community is then dominated by diatoms, which sustained a higher specific photosynthetic rate, $P_{B m}\left(7.21 \mathrm{~g} \mathrm{C} \mathrm{g} \mathrm{Chla}^{-1} \mathrm{~h}^{-1}\right)$, than the other taxonomic groups. During the rest of the year, i.e. from September to June, stable density stratification is usually observed within the mixolimnion, with varying depths of the surface mixed layer of typically around $10-30 \mathrm{~m}$ (Fig. 2). During this time, nutrient supply for primary production is scarce (Pasche et al., 2012; Sarmento et al., 2012) and phytoplankton becomes nutrient-limited (Fig. 5). Cyanobacteria with a low $P_{B m}\left(1.13 \mathrm{~g} \mathrm{C} \mathrm{g} \mathrm{Chla}^{-1} \mathrm{~h}^{-1}\right)$ then dominated the community.

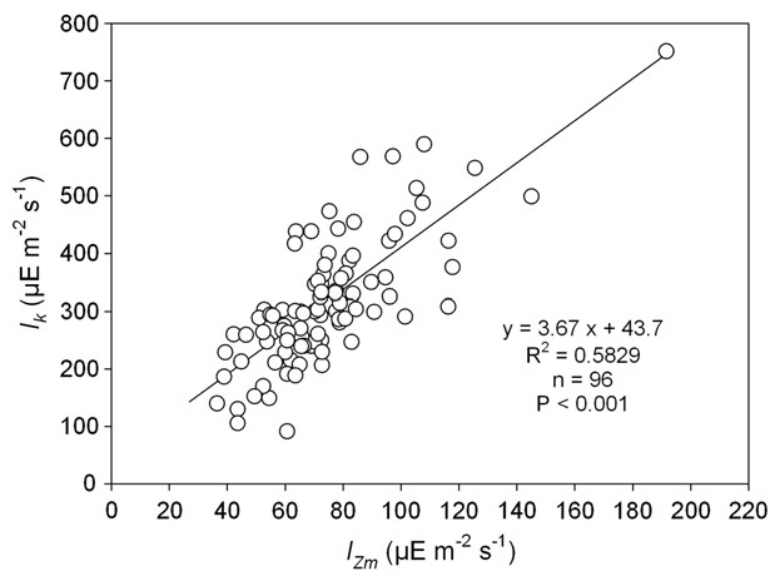

Fig. 7. Linear regression of the onset of light saturation of the phytoplankton $\left(I_{k}\right)$ against average light in the mixed layer $\left(I_{Z m}\right)$; data from ${ }^{14} \mathrm{C}$ incubations in Lake Kivu, Ishungu station (southern basin), 2002-2008. 
Table 2

Results of multiple linear regressions with forward stepwise selection between $P_{B m}$ as dependent variable and sample coordinates along the first 4 axes of the PCA with HPLC results and seston C:P and C:N ratios as explanatory variables. $n=96$.

\begin{tabular}{llll}
\hline Variables & Coefficient & $P$ & $R^{2}$ \\
\hline Origin & +3.560 & $<0.001$ & 0.658 \\
PCAaxis1 & +2.001 & $<0.001$ & \\
PCAaxis2 & +1.196 & $<0.001$ & \\
\hline
\end{tabular}

$P_{B m}$ was significantly correlated to both intracellular nutrient quota and phytoplankton taxonomic composition described by the principal components of a PCA. As the effects of nutrient supply and phytoplankton taxonomic composition are confounded in our field study, we cannot distinguish their respective role in controlling $P_{B m}$. It was demonstrated that $\mathrm{N}$ limitation in microalgae limits the amount of Chl $a$ and RubisCO, the key enzyme involved in photosynthetic fixation of carbon dioxide $\left(\mathrm{CO}_{2}\right)$ (Geider and MacIntyre, 2002; Turpin, 1991) and that $P_{B m}$ parallels $\mathrm{N}$ content in N-limited algae (Geider et al., 1998). Moreover, P starvation limited also $P_{B m}$ and the contribution of RubisCO to cell protein in Dunaliella tertiolecta Butcher (Geider et al., 1998).

Nevertheless, the best prediction of $P_{B m}$ in Lake Kivu was obtained by a regression model including the first principal component of a PCA analysis, used as synthetic descriptor of the phytoplankton taxonomic composition. This approach generated estimates of $P_{B m}$ which depended primarily on the dominant phytoplankton groups according to season. We were able to calculate $P_{B m}$ specific to each important

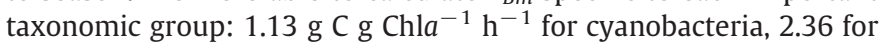
cryptophytes, and 7.21 for diatoms. The physiological basis for these large differences among phytoplankton depends on inorganic $\mathrm{C}$ fixation mechanisms and therefore on the specific properties of RubisCO, as discussed by Tortell (2000). Indeed, RubisCO exists in different forms in photosynthetic organisms (Falkowski and Raven, 2007) and differs largely in affinity and specificity for $\mathrm{CO}_{2}$. The specificity is measured by the ratio between the $\mathrm{CO}_{2}$ fixation rate and the $\mathrm{O}_{2}$ fixation rate when $\mathrm{CO}_{2}$ and $\mathrm{O}_{2}$ are at limiting concentrations: the higher the value of the ratio, the higher the affinity for $\mathrm{CO}_{2}$ relative to $\mathrm{O}_{2}$ (Falkowski and Raven, 2007). Most cyanobacteria, including Synechococcus sp., abundant in tropical lakes (Sarmento, 2012), have high affinity and low specificity, whereas diatoms are among the eukaryotes having the lowest affinity and highest specificity (Falkowski and Raven, 2007; Tortell, 2000). This would give diatoms a higher inherent capacity for C-fixation relative to photorespiration and may explain the high $P_{B m}$ we found for this phytoplankton group.

The irradiance at the onset of light saturation, $I_{k}$, was highly correlated to the average light in the mixed layer, $I_{Z m}$ (Fig. 7). For a given taxon,

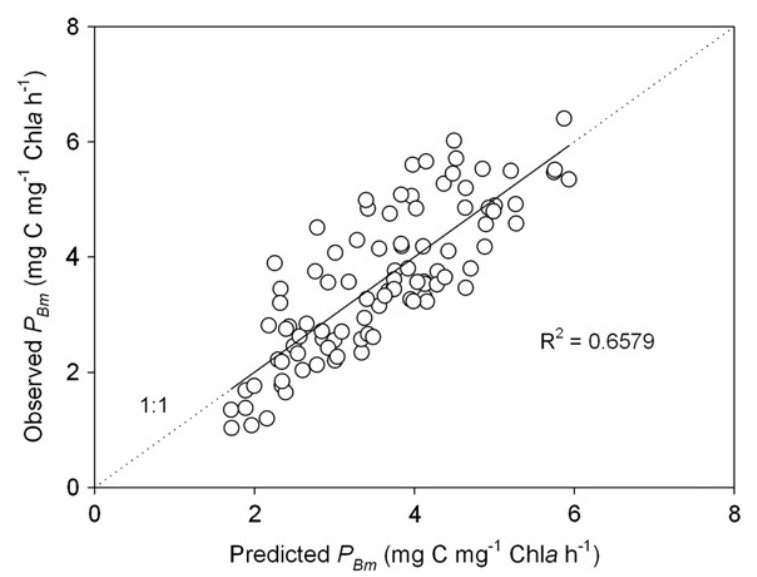

Fig. 8. Plot of observed vs predicted photosynthetic capacity $\left(P_{B m}\right)$ of the phytoplankton in Lake Kivu, Ishungu station (southern basin), 2002-2008.
Table 3

Sensitivity analysis of the daily primary production model. Each variable was replaced by its mean in turn while holding all other variables at their original values. The main absolute relative error of daily primary production (MARE, in \%) was computed for each variable. A high value indicates that the model is sensitive to the variable. Variables are classified by decreasing order of MARE.

\begin{tabular}{|c|c|c|}
\hline Variables & Mean & MARE \\
\hline Biomass & 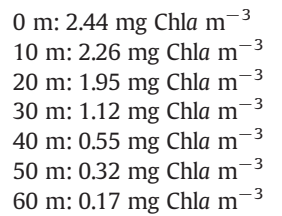 & $38 \%$ \\
\hline$P_{B m}{ }^{\mathrm{a}}$ & $3.57 \mathrm{mg} \mathrm{C} \mathrm{mg}^{-1} \mathrm{Chla} \mathrm{h}^{-1}$ & $27 \%$ \\
\hline$K_{e}$ (only directly) $^{\mathrm{b}}$ & $0.26 \mathrm{~m}^{-1}$ & $18 \%$ \\
\hline$I_{k}^{\mathrm{c}}$ & $318 \mu \mathrm{E} \mathrm{m}^{-2} \mathrm{~s}^{-1}$ & $17 \%$ \\
\hline$Z_{m}{ }^{\mathrm{d}}$ & $21.6 \mathrm{~m}$ & $17 \%$ \\
\hline$K_{e}^{\mathrm{e}}$ & $0.26 \mathrm{~m}^{-1}$ & $10 \%$ \\
\hline
\end{tabular}

${ }^{\text {a }} P_{B m}$ in the model is predicted by the algae community composition.

b $K_{e}$ influences the daily primary production both directly and indirectly (through its influence on $I_{k}$ ); in this line only the direct effect is evaluated.

c $I_{k}$ in the model is predicted by $I_{Z m}$, which is calculated from $Z_{m}$ and $K_{e}$

d $Z_{m}$ in the model influences $I_{Z m}$ and therefore $I_{k}$

e The direct and indirect effects of $K_{e}$ on the daily primary production is evaluated.

$I_{k}$ is influenced by both temperature and available light (Kirk, 1994). Given the small range of temperature variation in tropical lakes, it is expected that $I_{k}$ would be best predicted by available light in the mixed layer, which is itself, given by the relative constancy of $I_{0}$ in tropical regions, governed by the depth of the mixed layer $\left(Z_{m}\right)$ and by the vertical light attenuation coefficient $\left(K_{e}\right)$. A low $I_{k}$ is characteristic of phytoplankton adapted to low light, i.e. able of developing their maximal photosynthetic rate at low mean irradiance induced by deep mixing, and having accessory photosynthetic pigments. This situation occurs in deep tropical lakes in the dry season conditions, selecting for diatoms, which are also favored by increased nutrient supply and reduced sedimentation losses (Reynolds, 2006b). In contrast, high $I_{k}$ occurred in Lake Kivu when $I_{Z m}$ was high due to stratification of the mixolimnion reducing the mixing depth, selecting for high-light-adapted phytoplankton, able to face $\mathrm{N}$ depletion, such as cyanobacteria. So, to a large extent, the variation of $I_{k}$ in deep tropical lakes reflects seasonal variations of the environmental factors that contribute to determine the phytoplankton assemblage (Stenuite et al., 2007).

A key feature of Lake Kivu, already pointed out by Spigel and Coulter (1996), is the weak thermal gradient in the mixolimnion, due to its location at high altitude, where air temperature is lower than in the regions of the other East African great lakes. Then the density gradient in surface waters is always weak (Schmid and Wüest, 2012). Stratification conditions are therefore not constant during the rainy season and short mixing events may alternate with episodes of stratification (Fig. 2C). This leads to short periods of phytoplankton development out of the dry season, as observed by example during the rainy season 2006. On average, half of the annual primary production occurred nevertheless during the 4 months of the dry season. But exceptions to this general pattern are not rare: dry season phytoplankton peaks were not observed during 3 years (2002, 2005 and 2007) out of 7 (Fig. 2). Consequently, the absence of the dry season peak directly heavily impacted the mean annual primary production. For example, the absence of a complete mixing within the mixolimnion during the dry season 2007 led to a low annual primary production ( $143 \mathrm{~g} \mathrm{C} \mathrm{m}^{-2} \mathrm{y}^{-1}$ ) compared to the situation in 2008 where a complete overturn of the mixolimnion was observed during the dry season, producing a high phytoplankton biomass over the whole mixed layer and an annual production of $278 \mathrm{~g} \mathrm{C} \mathrm{m}^{-2} \mathrm{y}^{-1}$.

This demonstrates the sensitivity of tropical lakes to climate variability, as emphasized by several authors (e.g. Johnson and Odada, 1996; Descy and Sarmento, 2008). If the weather conditions leading to the 
Table 4

Volumetric (average in the euphotic zone) and total areal chlorophyll $a$ (Chla) concentrations, mean annual primary production (PP) in the pelagic zone of the East African great lakes. (1) Sarmento et al. (2012) and unpublished results (Jean-Pierre Descy, pers. comm.), ${ }^{(2)}$ volumetric Chla from Descy et al. (2005), areal Chla and CNP data from Descy et al. (2006), PP data from Stenuite et al. (2007); (3) Bergamino et al. (2010) and unpublished results (Nadia Bergamino, pers. comm.); ${ }^{(4)}$ Degnbol (1993); ${ }^{(5)}$ Guildford et al. (2000); ${ }^{(6)}$ Patterson et al. (2000); (7) Guildford et al. (2007); ${ }^{(8)}$ Mugidde (1993); (9) Guildford and Hecky (2000); ${ }^{(10)}$ Mugidde (2001); ${ }^{(11)}$ Silsbe (2004) using a photosynthetic quotient of 1 .

\begin{tabular}{|c|c|c|c|c|}
\hline & & $\begin{array}{l}\text { Chla } \\
\left(\mathrm{mg} \mathrm{m}^{-3}\right)\end{array}$ & $\begin{array}{l}\text { Chla } \\
\left(\mathrm{mg} \mathrm{m}^{-2}\right)\end{array}$ & $\begin{array}{l}\text { PP } \\
\left(\mathrm{g} \mathrm{C} \mathrm{m}^{-2} \mathrm{y}^{-1}\right)\end{array}$ \\
\hline \multirow[t]{8}{*}{ L. Kivu (southern basin) } & 2002 & 1.77 & 57 & 223 \\
\hline & 2003 & 2.31 & 80 & 264 \\
\hline & 2004 & 2.55 & 83 & 236 \\
\hline & 2005 & 1.63 & 53 & 153 \\
\hline & 2006 & 2.58 & 74 & 192 \\
\hline & 2007 & 2.04 & 73 & 143 \\
\hline & 2008 & 2.89 & 100 & 278 \\
\hline & Mean & 2.23 & 74 & 213 \\
\hline \multirow{5}{*}{ L. Kivu (eastern basin) ${ }^{(1)}$} & 2005 & 2.11 & 91 & \\
\hline & 2006 & 1.94 & 63 & \\
\hline & 2007 & 2.03 & 65 & \\
\hline & 2008 & 2.10 & 88 & \\
\hline & Mean & 2.03 & 77 & \\
\hline \multirow{3}{*}{$\begin{array}{l}\text { L. Tanganyika } \\
\text { (off Kigoma) }^{(2)}\end{array}$} & 2002 & 0.64 & 36.4 & 123 \\
\hline & 2003 & 0.59 & 37.3 & 130 \\
\hline & 2004 & & 35.8 & \\
\hline \multirow{3}{*}{$\begin{array}{l}\text { L. Tanganyika } \\
\text { (off Mpulungu) }{ }^{(2)}\end{array}$} & 2002 & 0.71 & 38.3 & 175 \\
\hline & 2003 & 0.73 & 41.3 & 205 \\
\hline & 2004 & & 34.4 & \\
\hline $\begin{array}{l}\text { L. Tanganyika } \\
\qquad \text { (whole lake) }\end{array}$ & 2003 & 1.06 & 42.9 & 236 \\
\hline \multirow{2}{*}{ L. Malawi (pelagic) ${ }^{(4)}$} & 1977-1981 & & 27.0 & 271 \\
\hline & 1990-1991 & 0.51 & 23.0 & \\
\hline \multirow[t]{2}{*}{ (6) } & 1992 & & & 329 \\
\hline & 1993 & & & 518 \\
\hline (7) & $1997-2000$ & 0.86 & 34.4 & 169 \\
\hline \multirow{2}{*}{$\begin{array}{l}\text { L. Victoria (near offshore) } \\
(9)\end{array}$} & 1989-1991 & 24.5 & 330.8 & $1903^{\mathrm{a}}$ \\
\hline & $\begin{array}{l}\text { 1990, } \\
1992-1996\end{array}$ & 26.5 & & \\
\hline (10) & $1994-1998$ & 13.5 & & \\
\hline \multirow{2}{*}{$\begin{array}{l}\text { L. Victoria } \\
\text { (lake-wide averages) }{ }^{(11)}\end{array}$} & $2000^{\mathrm{b}}$ & 10.7 & 116.5 & $1302 / 366^{c}$ \\
\hline & $2001^{d}$ & 10.5 & 106.9 & $1350 / 236^{c}$ \\
\hline
\end{tabular}

a Gross primary production estimated by the $\mathrm{O}_{2}$ light and dark technique and converted into $C$ using a photosynthetic quotient of 1 .

b Mean of the February and August 2000 cruises.

c Respectively, gross and net primary productions estimated by the $\mathrm{O}_{2}$ light and dark technique and converted into $\mathrm{C}$ using a photosynthetic quotient of 1 .

d Mean of the February and August 2001 cruises.

seasonal mixolimnion cooling and overturn are well understood, regional drivers of the inter-annual variability of the limnology of Lake Kivu are not yet explored. The East African climate was shown to be highly sensitive to sea-surface temperatures in the tropical Atlantic and Indian Oceans (Nicholson, 1996; Tierney et al., 2013). For example, the weather of the area centered around Lake Tanganyika is influenced by the El-Niño Southern Oscillation but timing and magnitude of this teleconnection are controlled by the local climate system (Plisnier et al., 2000).

Table 5

$P$ values from Mann-Whitney $U$ tests performed between individual East African great lakes for the variables and data presented in Table 4 . Significant values at the 0.05 leve are in bold.

\begin{tabular}{llcc}
\hline & Volumetric Chla & Areal Chla & Net PP \\
\hline Lake Kivu vs Lake Tanganyika & 0.003 & $<0.001$ & 0.234 \\
Lake Kivu vs Lake Malawi & 0.041 & 0.014 & 0.165 \\
Lake Kivu vs Lake Victoria & 0.003 & 0.014 & 0.241 \\
Lake Tanganyika vs Lake Malawi & 0.846 & 0.030 & 0.111 \\
Lake Tanganyika vs Lake Victoria & 0.012 & 0.023 & 0.118 \\
Lake Malawi vs Lake Victoria & 0.081 & 0.081 & 0.817 \\
\hline
\end{tabular}

A comparison of phytoplankton biomass and production data from East African Great Lakes shows that volumetric and areal biomass in Lake Kivu was higher than in lakes Tanganyika or Malawi but lower than in Lake Victoria (Tables 4 and 5). However, the annual primary production in Lake Kivu was in the same range as that in lakes Tanganyika or Malawi and no statistical difference can be observed between the phytoplankton production of these lakes (Table 5). Severe eutrophication of Lake Victoria, resulting into the highest pelagic Chla biomass for the East African great lakes (Table 4), arose from an important increase of human-population and agricultural activity from the 1930s onwards in its drainage basin (Verschuren et al., 2002). Higher phytoplankton biomass is still observed in the littoral areas and in closed bays (see e.g. Silsbe et al., 2006). Despite this higher Chla concentration in Lake Victoria, the net particulate primary production in the pelagic of Lake Victoria is surprisingly in the same range as those of the other East African Great Lakes (Tables 4 and 5). This low net productivity is most probably caused by self-shading, reducing the euphotic layer and inducing low light availability, as described for many other eutrophic lakes (e.g. Hubble and Harper, 2001; Vareschi, 1982).

Higher nutrient concentrations are usually observed in surface waters of Lake Kivu than in Lake Tanganyika (Sarmento et al., 2006). Soluble reactive phosphorus (SRP) in the euphotic zone of Lake Kivu was on average $0.44 \mu \mathrm{M}$ in rainy season and $0.75 \mu \mathrm{M}$ in dry season in 2002-2005; mean SRP in the euphotic layer of Lake Tanganyika was 0.19 and 0.43 in rainy season and dry season, respectively, in 2002 off Kigoma (Sarmento et al., 2006). The average dissolved inorganic nitrogen (DIN) in Lake Kivu was 2.42 and $3.29 \mu \mathrm{M}$ in the rainy season and the dry season, respectively. This contrast with lower DIN in Lake Tanganyika off Kigoma (mean rainy season DIN: $0.48 \mu \mathrm{M}$; mean dry season DIN: $0.69 \mu \mathrm{M}$ ). In Lake Malawi, annual means of total P and total $\mathrm{N}$ were 0.25 and $6.7 \mu \mathrm{M}$, respectively (Guildford et al., 2000). So, if Lake Kivu presents higher P concentrations in surface waters than in lakes Tanganyika and Malawi, Lake Malawi presents higher N concentrations than the other two lakes. Nevertheless phytoplankton of the three lakes present periods of single or combined $\mathrm{N}$ and/or $\mathrm{P}$ limitations (De Wever et al., 2008; Guildford et al., 2003; Sarmento et al., 2012). Differences in nutrient concentrations, and especially $\mathrm{P}$, between these lakes may help to explain the higher phytoplankton biomass we observed in Lake Kivu compared to lakes Tanganyika and Malawi.

An alternative but not exclusive hypothesis is linked to the food web structure, which allows a lower grazing pressure from the metazooplankton in Lake Kivu than in the other large Rift lakes. In 1959, Limnothrissa miodon Boulenger, a clupeid endemic to Lake Tanganyika, was introduced into Lake Kivu (Snoeks et al., 2012) in order to fill the empty pelagic niche and provide proteins for the local population. The planktivorous "Tanganyika sardine" may have led to the extinction of the cladoceran Daphnia curvirostris Eylmann, an efficient grazer and nutrient recycler (Dumont, 1986), which was presumably present in the lake in the 1950s. The current zooplankton is dominated by cyclopoid copepods, which are less efficient grazers (Isumbisho et al., 2006). Further, predation by the sardine has led to a reduction of zooplankton biomass, which has reduced the top-down control over phytoplankton (Darchambeau et al., 2012). The absence of an efficient grazer in Lake Kivu, as those present in lakes Tanganyika and Malawi, may help to explain why phytoplankton biomass observed in Lake Kivu is relatively high, despite phytoplankton productivity is of the same magnitude as in lakes Malawi and Tanganyika.

Huge amounts of $\mathrm{CO}_{2}$ and methane $\left(\mathrm{CH}_{4}\right)\left(300 \mathrm{~km}^{3}\right.$ and $60 \mathrm{~km}^{3}$, respectively, at $0{ }^{\circ} \mathrm{C}$ and $1 \mathrm{~atm}$ ) are dissolved in the deep water layers of Lake Kivu (Degens et al., 1973; Schmid et al., 2005). Around one third of $\mathrm{CH}_{4}$ originates from acetoclastic methanogenesis of sedimentary organic material, the other two thirds is produced by reduction of geogenic $\mathrm{CO}_{2}$ (Schoell et al., 1988; Pasche et al., 2011). Deep gas concentrations increased by $15-20 \%$ for $\mathrm{CH}_{4}$ and $10 \%$ for $\mathrm{CO}_{2}$ in the past 30 years (Schmid et al., 2005). In an attempt to explain the increase of $\mathrm{CH}_{4}$ concentrations in deep waters, Schmid et al. (2005) simulated the 
$\mathrm{CH}_{4}$ production along the 990 last years. They concluded that the historical $\mathrm{CH}_{4}$ production rate rose from an historical constant production rate of $30 \mathrm{~g} \mathrm{C} \mathrm{m}^{-2} \mathrm{y}^{-1}$ to $100 \mathrm{~g} \mathrm{C} \mathrm{m}^{-2} \mathrm{y}^{-1}$ between 1974 and 2004. Such a 3-fold increase would have been possible if an equivalent increase of primary production in the mixolimnion had occurred. In order to evaluate a possible increase of primary production in the lake, few historical data are available: Degens et al. (1973) and Jannasch (1975) reported a range of mean daily production of, respectively, $1.03-1.44 \mathrm{~g} \mathrm{C} \mathrm{m}^{-2} \mathrm{~d}^{-1}$ and 0.66-1.03 $\mathrm{g} \mathrm{C} \mathrm{m}^{-2} \mathrm{~d}^{-1}$, whereas Descy (1990) measured a rate of $0.33 \mathrm{~g} \mathrm{C} \mathrm{m}^{-2} \mathrm{~d}^{-1}$ in the pelagic zone. According to our estimates, the present daily primary production in Lake Kivu spans over a wide range of values, from 0.14 to $1.92 \mathrm{~g} \mathrm{C} \mathrm{m}^{-2} \mathrm{~d}^{-1}$, with a mean of $0.62 \mathrm{~g} \mathrm{C} \mathrm{m}^{-2} \mathrm{~d}^{-1}$. This range of variation covers well the few historic observations, allowing the conclusion that there was no important change of the lake's primary production in the pelagic zone over the last 40 years.

Other hypotheses than lake eutrophication for explaining the $\mathrm{CH}_{4}$ increase should then be envisaged. These hypotheses would involve an increased net sedimentation flux of $\mathrm{C}$ and nutrients due to environmental modifications as observed from analyses of sediments cores (Pasche et al., 2010, 2011). Among these modifications, the introduction of the Tanganyika sardine, L. miodon, at the end of the 1950s might have been a key event leading to ecological and geochemical changes. The possible consequences of this introduction, involving a trophic cascade effect with a reduction of the grazing pressure on phytoplankton and a subsequent increase of net sedimentation of organic matter, are further discussed by Darchambeau et al. (2012) and Descy et al. (2012). However, the extent of the changes in the food web is still difficult to evaluate from the present data, and an improved understanding will likely result from further paleolimnological studies based on various proxies of past productivity and phytoplankton composition.

\section{Conflict of interest}

There is no conflict of interest.

\section{Acknowledgments}

We are grateful to Mwapu Isumbisho, Georges Alunga, Pascal Masilya and Bruno Leporcq for field and laboratory assistance. H.S. benefited from fellowships from Brazilian "Ciências sem Fronteiras" Program from CAPES (BJT 013/2012). The study was supported by projects and grants from different Belgian institutions: CUD ("Commission Universitaire pour le Développement"), FRS-FNRS ("Fonds de la Recherche Scientifique"). The study is a contribution to EAGLES (East African Great Lakes Sensitivity to changes, SD/AR/02A), supported by BELSPO, the Belgian Federal Science Policy Office. FD was a postdoctoral researcher at FRS-FNRS.

\section{References}

Bergamino N, Horion S, Stenuite S, Cornet Y, Loiselle S, Plisnier P-D, et al. Spatio-temporal dynamics of phytoplankton and primary production in Lake Tanganyika using a MODIS based bio-optical time series. Remote Sens Environ 2010;114:772-80.

Borges AV, Abril G, Delille B, Descy J-P, Darchambeau F. Diffusive methane emissions to the atmosphere from Lake Kivu (Eastern Africa). J Geophys Res 2011;116: G03032.

Cermeño P, Marañon E, Rodríguez J, Fernández E. Large-sized phytoplankton sustain higher carbon-specific photosynthesis than smaller cells in a coastal eutrophic ecosystem. Mar Ecol Prog Ser 2005;297:51-60.

Claustre H, Hooker SB, Van Heukelem L, Berthon J-F, Barlow R, Ras J, et al. An intercomparison of HPLC phytoplankton pigment methods using in situ samples: application to remote sensing and database activities. Mar Chem 2004;85:41-61.

Cohen AS, Lezzar KE, Cole J, Dettman D, Ellis GS, Gonneea ME, et al. Late Holocene linkages between decade-century scale climate variability and productivity at Lake Tanganyika, Africa. J Paleolimnol 2006;36:189-209.

Darchambeau F, Isumbisho M, Descy J-P. Zooplankton of Lake Kivu. In: Descy J-P, Darchambeau F, Schmid M, editors. Lake Kivu: limnology and geochemistry of a tropical great lake. Dordrecht: Springer; 2012. p. 107-26.
De Wever A, Muylaert K, Langlet D, Alleman L, Descy J-P, André L, et al. Differential responses of phytoplankton additions of nitrogen, phosphorus and iron in Lake Tanganyika. Freshw Biol 2008;53:264-77.

Degens ET, von Herzen RP, Wong H-K, Deuser WG, Jannasch HW. Lake Kivu: structure, chemistry and biology of an East African Rift Lake. Geol Rundsch 1973;62: 245-77.

Degnbol P. The pelagic zone of central Lake Malawi -a trophic box model. In: Christensen V, Pauly D, editors. Trophic models of aquatic ecosystems. Makati: ICLARM; 1993. p. $110-5$.

Descy J-P. Etude de la production planctonique au lac Kivu -Rapport de mission. Projet PNUD/FAO - RWA/87/012. Namur: UNECED; 1990.

Descy JP, Sarmento H. Microorganisms of the East African Great Lakes and their response to environmental changes. Freshw Rev 2008;1:59-73.

Descy J-P, Hardy M-A, Sténuite S, Pirlot S, Leporcq B, Kimirei I, et al. Phytoplankton pigments and community composition in Lake Tanganyika. Freshw Biol 2005;50: 668-84.

Descy J-P, Plisnier P-D, Leporcq B, Sténuite S, Pirlot S, Stimart J, et al. Climate variability as recorded in Lake Tanganyika (CLIMLAKE). Final report. Brussels: Belgian Science Policy; 2006.

Descy J-P, Darchambeau F, Schmid M. Lake Kivu research: conclusions and perspectives. In: Descy J-P, Darchambeau F, Schmid M, editors. Lake Kivu: limnology and geochemistry of a tropical great lake. Dordrecht: Springer; 2012. p. 181-90.

Dumont HJ. The Tanganyika sardine in Lake Kivu: another ecodisaster for Africa? Environ Conserv 1986;13:143-8.

Falkowski PG, Raven JA. Aquatic photosynthesis. Princeton: Princeton University Press; 2007.

Fee EJ. Computer programs for calculating in situ phytoplankton photosynthesis. Can Technol Rep Fish Aquat Sci 1990;1740:1-27.

Fietz S, Nicklish A. An HPLC analysis of the summer phytoplankton assemblage in Lake Baikal. Freshw Biol 2004;49:332-45.

Fietz S, Kobanova G, Izmesteva L, Nicklisch A. Regional, vertical and seasonal distribution of phytoplankton and photosynthetic pigments in Lake Baikal. J Plankton Res 2005;27:793-810.

Geider RJ, MacIntyre HL. Physiology and biochemistry of photosynthesis and algal carbon acquisition. In: Williams PJ, le B, Thomas DN, Reynolds CS, editors. Phytoplankton productivity: carbon assimilation in marine and freshwater ecosystems. Oxford: Blackwell; 2002. p. 44-77.

Geider RJ, MacIntyre HL, Kana TM. A dynamic regulatory model of phytoplanktonic acclimation to light, nutrients, and temperature. Limnol Oceanogr 1998;43:679-94.

Gran G. Determination of the equivalence point in potentiometric titrations of seawater with hydrochloric acid. Oceanol Acta 1952;5:209-18.

Greene RM, Geider RJ, Falkowski PG. Effect of iron limitation on photosynthesis in a marine diatom. Limnol Oceanogr 1991;36:1772-82.

Guildford SJ, Hecky RE. Total nitrogen, total phosphorus, and nutrient limitation in lakes and oceans: is there a common relationship? Limnol Oceanogr 2000;45:1213-23.

Guildford SJ, Bootsma HA, Fee EJ, Hecky RE, Patterson G. Phytoplankton nutrient status and mean water column irradiance in Lakes Malawi and Superior. Aquat Ecosyst Health 2000;3:35-45.

Guildford SJ, Hecky RE, Taylor WD, Mugidde R, Bootsma HA. Nutrient enrichment experiments in tropical great lakes Malawi/Nyasa and Victoria. J Great Lakes Res 2003;29(Suppl. 2):89-106.

Guildford SJ, Bootsma HA, Taylor WD, Hecky RE. High variability of phytoplankton photosynthesis in response to environmental forcing in oligotrophic Lake Malawi/Nyasa. J Great Lakes Res 2007;33:170-85.

Hecky RE, Fee EJ. Primary production and rates of algal growth in Lake Tanganyika. Limnol Oceanogr 1981;26:532-47.

Hecky RE, Kling HJ. Phytoplankton ecology of the great lakes in the rift valleys of Central Africa. Arch Hydrobiol Beih Ergebn Limnol 1987;25:197-228.

Hubble DS, Harper DM. Impact of light regimen and self-shading by algal cells on primary productivity in the water column of a shallow tropical lake (Lake Naivasha, Kenya). Lakes Reserv Res Manag 2001;6:143-50.

Isumbisho M, Sarmento H, Kaningini B, Micha JC, Descy JP. Zooplankton of Lake Kivu, East Africa, half a century after the Tanganyika sardine introduction. J Plankton Res 2006;28:971-89.

Jannasch HW. Methane oxidation in Lake Kivu (central Africa). Limnol Oceanogr 1975;20: 860-4.

Jeffrey SW, Mantoura RFC, Wright SW. Phytoplankton pigments in oceanography. Paris: SCOR - UNESCO; 1997.

Johnson TC, Odada EO. The limnology, climatology and paleoclimatology of the East African lakes. Amsterdam: Gordon and Breach Publishers; 1996.

Kilham P, Kilham SS, Hecky RE. Hypothesized resource relationships among African planktonic diatoms. Limnol Oceanogr 1986;31:1169-81.

Kirk J. Light and photosynthesis in aquatic ecosystems. 2nd ed. Cambridge: Cambridge University Press; 1994.

Legendre P, Legendre L. Numerical ecology. 2nd ed. Amsterdam: Elsevier; 1998.

Lewis WMJ. Primary production in the plankton community of a tropical lake. Ecol Monogr 1974;44:377-409.

Llirós M, Descy J-P, Libert X, Morana C, Schmitz M, Wimba L, et al. Microbial ecology of Lake Kivu. In: Descy J-P, Darchambeau F, Schmid M, editors. Lake Kivu: limnology and geochemistry of a tropical great lake. Dordrecht: Springer; 2012. p. 67-83.

MacIntyre S. Climatic variability, mixing dynamics, and ecological consequences in the African Great Lakes. In: Goldman CR, Kumagai M, Robarts RD, editors. Climate change and global warming of inland waters. John Wiley \& Sons; 2012. p. 311-34.

Mackey MD, Mackey DJ, Higgins HW, Wright SW. CHEMTAX - a program for estimating class abundances from chemical markers: application to HPLC measurements of phytoplankton. Mar Ecol Prog Ser 1996;144:265-83.

Melack JM. Temporal variability of phytoplankton in tropical lakes. Oecologia 1979;44:1-7. 
Millero FJ, Graham TB, Huang F, Bustos-Serrano H, Pierrot D. Dissociation constants of carbonic acid in sea water as a function of salinity and temperature. Mar Chem 2006;100:80-94

Mugidde R. The increase in phytoplankton primary productivity and biomass in Lake Victoria (Uganda). Verh. Int. Ver. Limnol. 1993;25:846-9.

Mugidde R. Nutrient status and planktonic nitrogen fixation in Lake Victoria, Africa. [PhD thesis]Waterloo: University of Waterloo; 2001.

Nicholson SE. A review of climate dynamics and climate variability in Eastern Africa. In: Johnson TC, Odada EO, editors. The limnology, climatology and paleoclimatology of the East African lakes. Amsterdam: Gordon and Breach Publishers; 1996. p. $25-56$.

Pasche N, Alunga G, Mills K, Muvundja F, Ryves DB, Schurter M, et al. Abrupt onset of carbonate deposition in Lake Kivu during the 1960s: response to recent environmenta changes. J Paleolimnol 2010;44:931-46.

Pasche N, Schmid M, Vazquez F, Schubert CJ, Wüest A, Kessler JD, et al. Methane sources and sinks in Lake Kivu. J Geophys Res 2011;116:G03006.

Pasche N, Muvundja FA, Schmid M, Wüest A, Müller B. Nutrient cycling in Lake Kivu. In: Descy J-P, Darchambeau F, Schmid M, editors. Lake Kivu: limnology and geochemistry of a tropical great lake. Dordrecht: Springer; 2012. p. 31-45.

Patterson G, Hecky RE, Fee EJ. Effect of hydrological cycles on planktonic primary production in Lake Malawi/Niassa. In: Rossiter A, Kawanabe H, editors. Ancient lakes: biodiversity, ecology and evolution. London: Academic Press; 2000. p. 421-30.

Peltomaa E, Ojala A. Size-related photosynthesis of algae in a strongly stratified humic lake. J Plankton Res 2010;32:341-55.

Plisnier PD. Recent climate and limnology changes in Lake Tanganyika. Verh internat Verein Limnol 2000;27:2670-3.

Plisnier P-D, Serneels S, Lambin EF. Impact of ENSO on East African ecosystems: a multivariate analysis based on climate and remote sensing data. Glob Ecol Biogeogr 2000;9:481-97.

Reynolds CS. Ecology of phytoplankton. Cambridge: Cambridge University Press; 2006a.

Reynolds CS. The Ecology of Phytoplankton. New York: Cambridge University Press 2006b. p. 535.

Riley GA. Phytoplankton of the north central Sargasso Sea. Limnol Oceanogr 1957;2:252-70.

Sarmento H. New paradigms in tropical limnology: the importance of the microbial food web. Hydrobiologia 2012;686:1-14.

Sarmento H, Descy J-P. Use of marker pigments and functional groups for assessing the status of phytoplankton assemblages in lakes. J Appl Phycol 2008;20:1001-11.

Sarmento H, Isumbisho M, Descy J-P. Phytoplankton ecology of Lake Kivu (eastern Africa). J Plankton Res 2006:28:815-29.

Sarmento H, Leitao M, Stoyneva M, Couté A, Compère P, Isumbisho, et al. Diversity of pelagic algae of Lake Kivu (East Africa). Cryptogam Algol 2007;28:245-69.

Sarmento H, Isumbisho M, Stenuite S, Darchambeau F, Leporcq B, Descy JP. Phytoplankton ecology of Lake Kivu (eastern Africa): biomass, production and elemental ratios. Int Assoc. Theor. Appl. Limnol. 2009:30:709-13.

Sarmento H, Darchambeau F, Descy J-P. Phytoplankton of Lake Kivu. In: Descy J-P Darchambeau F, Schmid M, editors. Lake Kivu: limnology and geochemistry of a tropical great lake. Dordrecht: Springer; 2012. p. 67-83.

Sarvala J, Salonen K, Jarvinen M, Aro E, Huttula T, Kotilainen P, et al. Trophic structure of Lake Tanganyika: carbon flows in the pelagic food web. Hydrobiologia 1999;407:140-73.
Schmid M, Wüest A. Stratification, mixing and transport processes in Lake Kivu. In: Descy J-P, Darchambeau F, Schmid M, editors. Lake Kivu: limnology and geochemistry of a tropical great lake. Dordrecht: Springer; 2012. p. 13-29.

Schmid M, Halbwachs M, Wehrli B, Wüest A. Weak mixing in Lake Kivu: new insights indicate increasing risk of uncontrolled gas eruption. Geochem Geophys Geosyst 2005;6:1-11.

Schoell M, Tietze K, Schoberth SM. Origin of methane in Lake Kivu (East-Central Africa). Chem Geol 1988;71:257-65.

Segura V, Lutz VA, Dogliotti A, Silva RI, Negri RM, Akselman R, et al. Phytoplankton types and primary production in the Argentine Sea. Mar Ecol Prog Ser 2013;491:15-31.

Silsbe GM. Phytoplankton production in Lake Victoria, East Africa. [MSc thesis]Waterloo: University of Waterloo; 2004.

Silsbe GM, Hecky RE, Guildford SJ, Mugidde R. Variability of chlorophyll $a$ and photosynthetic parameters in a nutrient-saturated tropical great lake. Limnol Oceanogr 2006;51:2052-63.

Snoeks J, Kaningini B, Masilya P, Nyina-wamwiza L, Guillard J. Fishes in Lake Kivu: diversity and fisheries. In: Descy J-P, Darchambeau F, Schmid M, editors. Lake Kivu: limnology and geochemistry of a tropical great lake. Dordrecht: Springer; 2012. p. 127-52

Spigel RH, Coulter GW. Comparison of hydrology and physical limnology of the East African Great Lakes: Tanganyika, Malawi, Victoria, Kivu and Turkana (with references to some North American great lakes). In: Johnson TC, Odada EO, editors. The limnology, climatology and paleoclimatology of the East African lakes. Amsterdam: Gordon and Breach Publishers; 1996. p. 103-40.

Steeman-Nielsen $\mathrm{E}$. The use of radioactive carbon $\left({ }^{14} \mathrm{C}\right)$ for measuring organic production in the sea. J Cons Perm Int. Explor Mer 1952;18:117-40.

Stenuite S, Pirlot S, Hardy M-A, Sarmento H, Tarbe A-L, Leporcq B, et al. Phytoplankton production and growth rate in Lake Tanganyika: evidence of a decline in primary productivity in recent decades. Freshw Biol 2007;52:2226-39.

Talling JF. Photosynthetic activity of phytoplankton in East African lakes. Int Rev Ges Hydrobiol 1965;50:1-32.

ter Braak CJF, Šmilauer P. CANOCO reference manual and CanoDraw for Windows user's guide: software for canonical community ordination (version 4.5). Ithaca: Microcomputer Power; 2002

Tierney JE, Smerdon JE, Anchukaitis KJ, Seager R. Multidecadal variability in East African hydroclimate controlled by the Indian Ocean. Nature 2013;493:389-92.

Tortell PD. Evolutionary and ecological perspectives on carbon acquisition in phytoplankton. Limnol Oceanogr 2000;45:744-50.

Turpin DH. Effects of inorganic $\mathrm{N}$ availability on algal photosynthesis and carbon metabolism. J Phycol 1991;27:14-20.

Valderrama JC. The simultaneous analysis of total nitrogen and total phosphorus in natural waters. Mar Chem 1981;10:109-22.

Vareschi E. The ecology of Lake Nakuru (Kenya). III. Abiotic factors and primary production. Oecologia 1982;55:81-101.

Verschuren D, Johnson TC, Kling HJ, Edgington DN, Leavitt PR, Brown ET, et al. History and timing of human impact on Lake Victoria, East Africa. Proc R Soc Lond B 2002;269: 289-94.

Vollenweider RA. Calculations models of photosynthesis-depth curves and some implications regarding day rate estimates in primary production measurements. Mem Ist Ital Idrobiol 1965;18:425-57. 